\begin{tabular}{c} 
International Journal of Engineering \& Technology, $7(3.21)(2018) 404-407$ \\
International Journal of Engineering \& Technology \\
WPC \\
Website $: \underline{w w . s c i e n c e p u b c o . c o m / i n d e x . p h p / I J E T}$ \\
Research paper \\
\hline
\end{tabular}

\title{
Social Protection for Child Labors
}

\author{
Yuyun Yuningsih $^{1 *}$, Ummu Salamah $^{2}$, Nunung Nurwati $^{3}$ \\ ${ }^{1,2,3}$ Department of Social Welfare, Universitas Pasundan, Indonesia \\ *Corresponding author E-mail: yyuningsih27@gmail.com
}

\begin{abstract}
Socio-economic condition of the family often drives children to be directly involved in earning living expenses as workers. In the informal sector, Child labor is very prone to exploitation, discrimination, and violence. The purpose of this study is to discuss the implementation of social protection for child labor in Cibaduyut Region, Bandung, Indonesia. This study used descriptive qualitative approach. Informants were selected based on purposive sampling method. The informants covered child labor, family, and representation from a government agency and non-government agency involved in social protection program for child labor. Data collecting was obtained through interview and observation. The data were analyzed with the descriptive qualitative method. The research finding showed that social protection for child labor needs social assistance, social advocacy, and legal assistance. The result denoted that social protection program cannot be done effectively, comprehensively, and sustainability. This study used ecological perspective to understand the influential factors toward a social policy for child labor. Furthermore, the study recommended the enhancement of cooperation and coordination between stakeholders so that child labor can be treated effectively.
\end{abstract}

\section{Introduction}

In several areas, welfare condition of children are still poor. Children's rights to live and grow healthy, intelligent, cheerful, and virtuous have not been fulfilled and even beyond their expectation. The number of children who still have problems such as violences, exploitations and employed are fairly high. Ideally, children should be protected from a variety of behaviors and activities that disrupt their growth. Therefore, child labors' social rights such as gaining health, education, play, and grow like children, in general, need to be guaranteed(1).

According to the Conference on the Rights of Children (CRC),reported by the United Nations in 1992, thematterof child labors still remained an important issue related to the development of the global economy and could even encourage economic inequality between countries. Meanwhile, the ILO (International Labor Organization)stated that the number of child labors in Philippines whose age between 5 and 17 years reached 5.5 million children. Most of them, which are approximately 3 million child laborwere involved in dangerous work. Their work was involved in an employment that could impair their physical and mental health. The phenomenon of child labors also occurred in Bangladesh and Nepal. In both countries, there were 70,000 children under 14 years who work for a mining company in a dangerous and inhumane conditions in Jaintia Hills region, a State of Meghalaya in northern India(2).

In order to protectthe social rights of child labor, the CRC covered the following principles: the principle of eliminating child labors which mandatedevery member country that ratified it to make national policy to effectively ensure the elimination of child labors in all occupations. In addition, each country was obliged to progressively add the minimum age of children allowed to work until the conditions appropriate to workingpeople's physical and mental development needs. Furthermore, the principle of the protection of child labors was defined that the minimum age of children to work is 15 years. The age of 15 years is adopted from the compulsory school age at which children have graduated from junior high school(3).

This condition was followed and influenced by a community's economic condition lying under poverty and economic crisis which eventually encourage children to enter the work world. It is common for children from poor family to have economic functions to help their parents earn living expenses. However, involving children in economic or employment activities to earn income in both formal and informal sectors too early can harm the children's development. In fact, child labors experience a variety of physical, social, and psychological disorders(4).

As the aforementioned, social protection is an essential aspect of child labors. It is necessary to employ the social protection of child labors because children involved in earning living expenses in an informal sector are very vulnerable to the exploitations, discriminations, and violences. Based on the existing condition of child laborsabove, it is necessary to conduct a research, especially on social protection. The purpose of this study is to analyze the social protection carried out by various government and nongovernment institutions related to social aid, social advocacy, and legal assistance.

\section{Methodology}

This research employed a qualitative approach since the research problem is a dynamic social problem which requires a deep study on dealing with the problems of child labors in term of the implementation of child labors program management. In addition, qualitative research is a study that analyzes and reveals the attitude, view, feeling and behavior of an individual or a group of people as the object. Therefore, this qualitative study aims to reveal the phe- 
nomenon of the implementation of child labors program management carried out by various government and non-government institutions related to the existence of child labors.

Furthermore, this research tries to analyze and reveal the implementation of a social protection policy for child labors. Child labors in an informal sector have very poor condition. This research explores the social facts which stand alone or associated with the other phenomena of the child labors existences. As a matter of fact, there are a lot of child labors in various industries and companies, both small and medium that gettinginadequate social protection. The informants of this study are all people involved into the implementation of the child labors management in informal industry. Therefore, the subject of this research was conducted in an informal industry (stakeholders) that relate directly or indirectly to the child labors existence. The stakeholders include government agencies related to children protection or department associated with the child labors, non-Government Organizations (NGOs) associated with child labors, companies or industries that employ children, parents of child labors, children protection agency, and child labors in a variety of informal industries and enterprises.

\section{Result and Discussion}

\subsection{Result}

Social protection is a basis or foundation in realizing the child welfare and ensuring the future of children in their upcoming lifetime. Social protection aims to provide support and assistance to a poor family to cope with problems. The most beneficial social protection programs in eradicating child labors in accordance with ILO recommendation No 202 in 2012 on the foundation of basic social protection such as healthcare and income security, combined with the access to education and other critical services, can prevent child labors. Basic social protection program was designed as a social protection program "sensitive child" and especially sensitive child labors, in order to maximize the impact on child labors.

Moreover, the social protection is a 'multi-pillars' since it relates to the reform of pension, health insurance, or labor market(5). As an instrument of policy choices, social protection paradigm offers an assessment of the discourse, advocacy and development capital. The policy instrument is the actualization of the development vision combined with economic growth and poverty reduction. The above social protection is carried out through (a) Social assistance: intended for individual, family, groups and/or community experiencing social shock and vulnerability can live normal life; (b) Social Advocacy, intended to protect and defend a person, family, group, and/or people whose rights are violated; (c) Legal assistance: given in the form of advocacy and legal consultancy.

a. Social Assistance: The implementation of social protection program in a form of social assistance is the initial management prior to vulnerability. Preventing children from dropping out of school, especially from poor family and unlucky children, it is necessary to make prevention program through increasing the access to education.Social assistance program in a form of cash and goods aims to improve the family income security and facilitate the health care and education, with a condition or not, helping to prevent child labors. The programs are Reducing Child labors, Hoped Family Program, equivalent to the programsin package A, B, and $\mathrm{C}$ and entrepreneurship. Skilltraining and Micro Lending programs are the basic social protection programs to prevent child labors. Such programs can help the family economic resilience which caneliminate the involvement of children in work world. Based on an interview with the stakeholder of the Department of informal and non-formal Education, it was stated that the learners' participation for package A (elementary school level) and package B (junior high school level) was very good, many workers of school dropouts suc- ceeded to follow the equality package, but the participation for package A was very poor. There are many factors of its failure such as lack of support from parents as they considered that the graduates of higher education finally got low employment, in addition to the environment factor in which many children worked that affected the interest of child labors to attend school.

b. Social Advocacy: Advocacy is an activity of helping a client or group of clients to reach certain services when they are rejected in an institution or a service system, and help expand the service to include more people in need(6). The social advocacy employed to help eliminate child labors can be done through a change in employment policy by deciding a minimum age for a work permit, establishing the right rules on employment hours and conditions and determining the appropriate penalties or other sanctions to ensure an effective implementation. The protection of child labors is not regulated in the formulation of the law on child welfare. However, when looking at the issue of child labors within the children protection framework, it was stated that child labors are an act against this law. The formulationof children have the right to protection from their environment that may harm or inhibit their fair growth and development. This formulation is firmly related to the concept of child labors protection. In many places, children laborarealways in unfavorable and exploited condition. The condition of work can harm or inhibit the children natural growth and development.

c. Legal Assistance: providing wider legal protection for children. The legislation on child labors and children education must be consistent with its objectives and implemented in a way of supporting each other. The law on child labors must be in line with the UN's Convention on Child Rights and ILO Convention.

The research finding showed that the implementation of child labors social protection in Cibaduyut Bandung has been already carried out through the preventive, rehabilitative efforts and empowerment by involving various stakeholders in Bandung. The stakeholders already have an active participation to handle child labors through social assistance program, social advocacy, and legal assistance. They, however, should improve their coordination so that the dropout children labor have no difficulty in obtaining facilities to continue their education.

\subsection{Discussion}

Social protection is one of the social welfare effortsso called a tangible asset or an intervention of social protection as a whole, which includes many aspects. Employing social protection toward child labors can not be done through emphasizing only one particular aspect. This is related to the child labors problem of various aspects. Therefore, employing social protection toward child labors must be done through a variety of approacheswhich is theso-calledmulti-dimensionapproach(7). Such an approach does not only rely on the childaspect but also other aspects which encourage a child to work. The complex background of child labors must find its problem solving when employing a thorough social protection.

Multi-dimension approach is a model of social protection approach, particularly for child labors that aim "to the challenging task of promoting communities and state that are free of violence against child worker". A thorough social protection approach to child labors in the perspective of social welfare science or social work is applied to improve the ability of community, family, country, and children in overcoming the problem of child labors. It is intended to make an act of solving the child labors problem of the worst jobs that inhibit child growth and development. Moreover, such an approach can provide an opportunity for child labors to have a normal social function like any other children who enjoy the beautiful childhood such as playing and studying or gaining education and skills at schools. 
As presented above, the implementation of social protection for child labors has obstacles in its action. Social protection of child labors in the informal industrial center Cibaduyut, for instance, has been employed by ILO from 2003 until 2009. However, such protection program does not get its follow-up. It showed that social protection program conducted was temporary and not supported by the institution and office involved in running and continuing the program.

The implementation of social protection for child labors can employ the Chambers framework(8). In the implementation of a social protection program for child worker, there is needed ananalysis of the feasibility of a rule or legislation applied. The analysis of social legislation has some important questions: first, 'who get what'; second, 'how much'; and third 'under what conditions'.

Furthermore, the implementation of social protection can be measured from the 2 (two) specific criteria of eligibility. In this regard, the implementation of social protection toward child labors can be measured by 'stigmatization' and 'off-targeted benefits'( 8 ). The purpose of stigmatizationis the feasibility of a regulation made to ascertain whether the intended social legislation already provides the necessary social services to the recipient. Furthermore, 'off-targeted benefits' are the criteria used to analyze the feasibility of social legislation to assess the social values championed by connecting the implementation procedure. It seems possible that the implementation of a social legislation is much broader than the target outlined program or the purpose is beyond the planned program.

There is so a classic problem found in all the programs in Indonesia as well as other programs. The problems of budget or fund, coordination, responsibility, and many others make the program of child labors protection in Cibaduyut unsustainable. It is required an active role of all stakeholders in the implementation of social protection that promotes the rights of children. In addition, in order to employ the social protection, it is needed an ongoing fundingsupport from the government, awareness of all stakeholders related to the implementation of social protection.

With its weaknesses, this does not mean that the social protection for child labors can not be implemented and continued. Social protection is a form of public policy and intervention employed to respond a lot of risks, vulnerabilities and misery, whether physical, economic, and social, especially those are experienced by thepoor(9). The problems that hinder the social protection must find a solution so that the social protection of workers can be employed to ensure their future and the following generation. This requires a holistic or integral social protection which is so called social protection toward child labors in an integrated manner. Some stakeholders already own the programs that support the eradication of child labors, which has been done in industrial center area Cibaduyut, but it is still performed in every main tasks area. In addition,it is necessary to make a coordination and synergy of respective programs into unified activities. Observation, research finding, and the government's efforts in handling or reducing the child labors are still not optimal. Given the problem of child labors are complex and involve many parties, the problem should be solved in an integrated manner. In addition, the problem of child labors in the footwear sector is now no longer a priority of the local government, nor the city government.

However, this study attempted to make the management of child labors by adopting ecological theory. In an ecological theory or system theory, it is stated that a problem or something is interconnected between factors. Therefore, through the ecological theory, it can be understood that the growth of children, including child labors,is influenced by many factors. The factors that affect the growth and development of the child labors are a play group, a school friend, parents, community, and social environment. These factors do not affect only the individuals, the child workers, but these factors also influence each other reciprocally to the existence of child labors(10).
The perspective of the ecological approachis a suitable perspective for intervention application in a social work to handle social issues, including the child labors(11). This is because the intervention model is an attempt to direct all attention into a system. All the elements or factors in the system attempt to support the existence of a system. Child labors is a system whose factors are its elements which are supporting each other. Therefore, if one factor does not play a role or unable to perform the functions of the system, the management of child labors will not work well.

First, the social protection of child labors through a family approach. At the present time, the problem of child labors is not separable from his family. Family poverty is a major source of child labors. One concept of the family for children is that the children have a high economic value. This means that child labor has high economic value. By working, a child will add the family income. Therefore,the approach of social protection according to this system approach means that releasing child labors must involve the intervention of his family. In this case, the empowerment of the family is something compulsory so that social protection can be done to child labors. The basic important need for children is a harmonious relationship between parent and children. Attention and affectionare theneeds that must be met and realized. Therefore, it is necessary to make an intervention or implement social protection of child labors by family members. It is believed that the implementation of social protection which does not involve family will not achieve its target.

Second, the social protection of child labors can be employed through intervention approach for the child's environment or his peer-group. Despite its littlenumber, the influence of peers group of child labors can affect himto follow his group. However, this effect is very little or insignificant in affecting a peer-group to enter the workforce. Family poverty condition forces a child to enter the work world or become child labors. Therefore, preventinga child from being child labors and returning him to the family environment need the empowermentof parents. The point is when the parents of child labors can meet his needs through productive economic activity, the child will automatically be withdrawn from the work world and then enroll him inschool.

Third, the implementation of social protection of child labors can be employedby the school environment. This is due to the school environment as a factor that can affect the growth of child labors' personality, behavior, and thought. Child laborsalwaysmake social interaction with the surrounding social environment. The socialenvironment, in this case,is related to the social, cultural factors, especially in the school environment. Therefore, reducing the involvement of children in the footwear industry center in Cibaduyut can be employed through a social relationship in school. School can play a very big role for child labors, so he feels happy to enroll in school instead of working. This may be done through providing a continuous motivation so that child labors feel comfortable to follow educational activities at schools rather than workingoutside ofschool.

Fourth, child labors himself. The social protection of child labors can be based on the condition and need of the child labors. For example, child labors who commonlyhas a very low education are the basic problem of the child labors. In general, they haveelementary school education level. Therefore, in order to get free from the cycle of child labors that children occupied it is required to improve education for child workers. This can be realized by providing education to them. ILO, for example, has donated open school. Such a program, however, can not be executed because there are technical obstacles in the form of responsibility and funding. Therefore if you want to employ the social protection of child labors, the protection by providing educational services as a problem solving to improve the education of child labors is necessary. In fact, not only the level of educationgiven to the child labors is junior high school, but also the levels of junior high school and college. Education is an entry point for child labors to change himself for the better life. Education is a basic requirement for child labors and Indonesian 
children as a whole. Therefore, providing social protection in a form of education can cut the vicious circle of life and the future of child labors. Although such cases may have certain obstacles, we can saveand protect child labors throughproviding education. Fifth, the social protection of child labors can be employed through community or society intervention. A child'sgrowth and development are influenced by the social environment(11). The social environment includes family, neighbors, community, school, places of worship, and social structure of the greater community. Child labors have ecological system mentioned above. Therefore, in order to intervene the social environment of child labors one of which is the social environment of the stall owners in the footwear industrial center area in Cibaduyut.

They should understand that the industry is not allowed to involve child labors in the employment. However, it has been well known that the stalls that produce shoes are the third sub-contracts partwith a bigcorporation. Under this condition, they need child labor to cheap labors. Therefore, to performthe social protection of child labors need the awareness of the stall owners not to employ children in the business environment. In order to implement the policy, theauthority such as the Department of Labor must disseminate the information for the stalls not to employ the child labor.

\section{Conclusion}

The implementation of the social protection of child labor has involved all elements that affect the existence of child labors, but there are many obstacles in realizing children's right. Inadequate human resources, limited facilities, and financial support are very minimum. In addition, the implementation of social protection employed has involved a lot of institutions and stakeholders, but the result showed that it has not succeeded in defending and realizing the children's rights.

By taking look at child labor from each case perspective, it seems to be more difficult to make the social protection of child labor especially related to children's rights. Child labor is a single unit with their parents and environment. The social protection of child labor employed should include the social protection for their families and the environment too.

The social protection of child labor should set a priority to the principle of intelligent and qualified and children's rights. The problem of child labors is our problem as well, therefore the intervention should be based on ecology ranging from the micro level to the macro level, as overcoming priority. The social welfare for child labor must give priority to the principle of intelligent and qualified and the issue of children's rights. The problem of child labor is our problem as well so that the management must be conducted in a structural and systematic manner.

\section{References}

[1] Usman H, Nachrowi DN. Pekerja Anak di Indonesia: Kondisi Determinan dan Eksploitasi: Kajian Kuantitatif. Jakarta: Gramedia; 2004.

[2] ILO-IPEC. Kajian Terhadap Peraturan, Kebijakan, dan Programprogram Penghapusan Pekerja Anak di Indonesia. Jakarta: ILOIPEC; 2011.

[3] Huraerah A. Kekerasan Terhadap Anak. Bandung: Nuansa Cendikia; 2012.

[4] White B, Tjandraningsih I. Child Workers in Indonesia. Bandung: Akatiga; 1998.

[5] Adesina JO, Social T, Programme P. Rethinking the Social Protection Paradigm : Social Policy in Africa's Development. Soc Policy. 2010;28-30.

[6] Zastrow C. Social Work and Social Welfare. Cengage Learning; 2013.

[7] Ferguson H. What social workers do in performing child protection work: evidence from research into face-to-face practice. Child Fam
Soc Work. 2016;21(3):283-94.

[8] Donald C. Social Policy and Social Program. Boston: Allyn and Bacon; 2000.

[9] Suhartono E. Kemiskinan dan perlindungan sosial di Indonesia: menggagas model jaminan sosial universal bidang kesehatan. Bandung: Alfabeta; 2009.

[10]Rothery M. Critical Ecological Systems Theory. Theoretical Perspectives for Direct Social Work Practice: A generalist-Eclectic Approach. Ney York: Springer; 2016.

[11] Urie B. The ecology of human development. Harvard University Press; 2009. 